\title{
Relationship between food insecurity and overweight in preschool-aged children in rural West Virginia
}

\author{
Melissa Webber \\ West Virginia University
}

Follow this and additional works at: https://researchrepository.wvu.edu/etd

\section{Recommended Citation}

Webber, Melissa, "Relationship between food insecurity and overweight in preschool-aged children in rural West Virginia" (2007). Graduate Theses, Dissertations, and Problem Reports. 2546.

https://researchrepository.wvu.edu/etd/2546

This Thesis is protected by copyright and/or related rights. It has been brought to you by the The Research Repository @ WVU with permission from the rights-holder(s). You are free to use this Thesis in any way that is permitted by the copyright and related rights legislation that applies to your use. For other uses you must obtain permission from the rights-holder(s) directly, unless additional rights are indicated by a Creative Commons license in the record and/ or on the work itself. This Thesis has been accepted for inclusion in WVU Graduate Theses, Dissertations, and Problem Reports collection by an authorized administrator of The Research Repository @ WVU. For more information, please contact researchrepository@mail.wvu.edu. 


\title{
RELATIONSHIP BETWEEN FOOD INSECURITY AND OVERWEIGHT IN PRESCHOOL-AGED CHILDREN IN RURAL WEST VIRGINIA
}

\author{
Melissa Webber \\ Thesis submitted to the College of Agriculture, Forestry, and Consumer Sciences \\ at \\ West Virginia University \\ in partial fulfillment of the requirements \\ for the degree of \\ Master of Science \\ in \\ Animal and Nutritional Sciences \\ Cindy Fitch, Ph.D., R.D. Chair \\ Betty Forbes, R.D., L.D. \\ Kristen Matak, Ph.D.
}

Division of Animal and Nutritional Sciences

Morgantown, West Virginia

2007

Keywords: food insecurity, overweight, obesity, nutrition 


\section{ABSTRACT \\ Relationship Between Food Insecurity and Overweight in Preschool-Aged Children in Rural West Virginia}

\section{Melissa Webber}

The prevalence of overweight among adults and children continues to increase. The purpose of this study was to evaluate demographic factors that may be associated with an increase in a child's weight status. Subjects were children aged 2 to 6 years old in two southern West Virginia counties, McDowell and Mercer. Children were weighed and measured, and BMI was calculated. Parents or other caregivers were asked to complete a questionnaire regarding child's age, household food security, and parents' age, height and weight, education level, and hours worked per week.

A positive association between food insecurity and overweight among children was present $(\mathrm{p}=0.06)$. The mother's BMI was positively associated with the child's BMI $(p<0.05)$, however the father's BMI was positively associated with only the girl's BMI $(p=0.02)$. The only significant association with the parents' education was that dad's educational attainment was associated with an increase in boys' BMI. This study revealed important information regarding relationships between household demographics and overweight in children. 


\section{ACKNOWLEDGEMENTS}

I would like to thank my committee chair, Dr. Cindy Fitch, for her advice and encouragement throughout my education in nutrition. She has been very supportive as my advisor.

I thank Betty Forbes for her supportive and encouraging words. She brought a vast array of knowledge as a committee member. She has been very supportive and patient throughout my education.

Dr. Kristen Matak has brought great knowledge to my committee. I thank her for the vast array of enlightening questions and comments.

I would like to thank my loving parents, Jeff and Joyce Webber for their loving support and encouragement throughout my education and entire life.

I would also like to thank my sister Miranda Hayes, my grandparents, my loving boyfriend, and my close friends for their support, patience, and encouragement throughout my life. 


\section{Table of Contents}

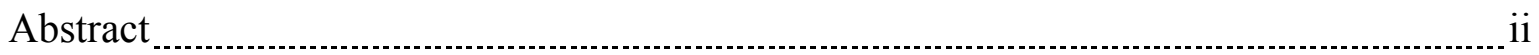

Acknowledgement

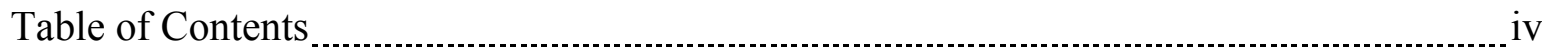

List of Tables $\ldots \ldots$

Introduction $\ldots \ldots \ldots$

Review of Literature

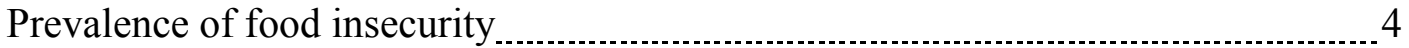

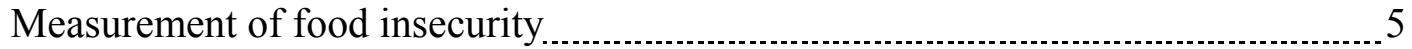

Definition of Overweight

Prevalence of Overweight _............................................................................... 6

Characteristics of McDowell and Mercer counties

Previous studies associating weight with food security status _............................... 8

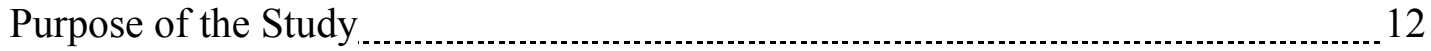

Methods

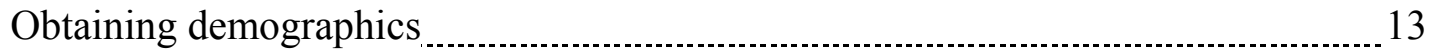

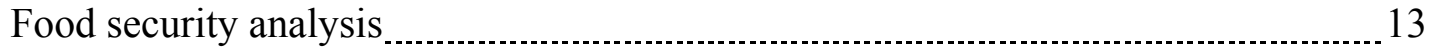

Statistical analysis $\ldots \ldots \ldots \ldots \ldots \ldots$

Results

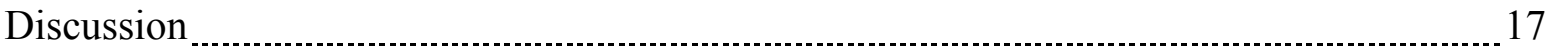

Conclusion 19

References

Appendices

Appendix $1 \ldots \ldots$

Appendix $2 \ldots$

Appendix $3 \ldots 2$

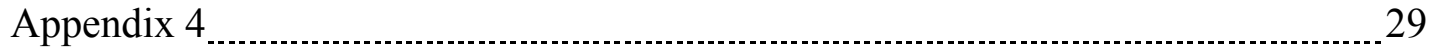

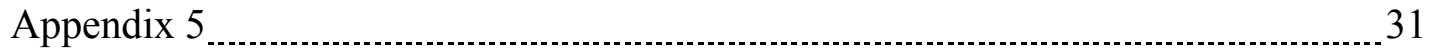

Appendix $6 \ldots$

Appendix $7 \ldots$

Vita 


\section{List of Tables}

Table 1: Defining weight status with BMI percentiles $\quad \frac{\text { Page }}{6}$

Table 2: Demographics of McDowell and Mercer counties .................................... 7

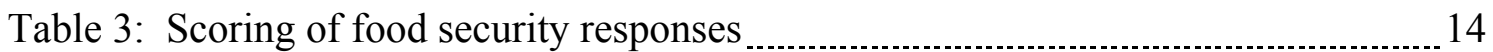

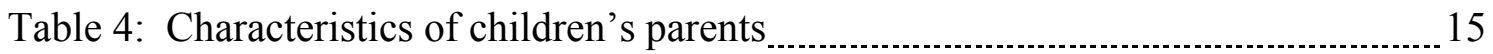

Table 5: Children's BMI categories in households experiencing various levels of food

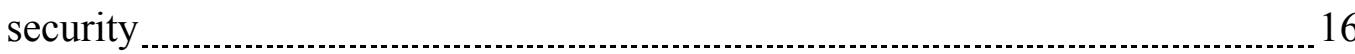




\section{$\underline{\text { Introduction }}$}

Food security is defined as access by all people at all times to enough food for an active, healthy life. At a minimum, food security includes the availability of nutritionally adequate and safe foods, and an assured ability to acquire acceptable foods in socially acceptable ways. This includes not resorting to emergency food supplies, scavenging, stealing, or other coping strategies. When there is limited or uncertain availability of nutritionally adequate and safe foods or ability to acquire acceptable foods in socially acceptable ways, food insecurity exists. Furthermore, hunger may be a consequence of food insecurity. Hunger due to food insecurity exists when there is an uneasy or painful sensation caused by a lack of food and/or recurrent and involuntary lack of access to food (Anderson 1990).

Since 1995, as a survey supplement of the annual Current Population Survey (CPS), the United States Department of Agriculture (USDA) has collected food security information for the U.S population. A major goal of the data collection by the USDA is to monitor the prevalence of food insecurity in U.S. households. Each year USDA summarizes their findings in the Measuring Food Security in the United States series. Prevalence of household-level food insecurity and food insecurity with hunger is also available for each state (Nord et al, 2005).

Food insecurity prevalence rates are substantially higher in particular populations, including: households with incomes below the Federal poverty line, households headed by single women with children, Black households, and Hispanic households. Food insecurity is also more common in the South and the West areas of the United States, and in central cities and rural areas than suburbs. Food insecure households tend to spend 
less for food than food secure households and are more likely to seek assistance from Federal food assistance programs such as the National School Lunch Program, the Food Stamp Program, and the Special Supplemental Nutrition Program for Women, Infants, and Children (WIC) (Nord et al, 2005).

Existence of food insecurity in a household tends to lead to various dietary and health consequences; for women, a significant decrease in consumption of fruits, vegetables, and vitamin C is seen (Kendall et al, 1996). Inadequate nutrient intake of vitamin B-6, vitamin D, vitamin E, iron, calcium, magnesium, zinc, and pantothenic acid has also been identified in diets of low-income families (Emmons 1986). Household food insecurity and/or a low income status also affect the health status of children. Johnson-Down and associates found that children, nine to twelve years old, of low income households had significantly lower intake of vitamins A, C, iron and folate (1997). Fifth grade (9.58+/-0.58 years old) Hispanic children of food insecure households have been seen to consume a significantly less amount of meat products than children of food secure households (Matheson 2002).

Food insecurity and hunger are also associated with decreased health status in children. In a group of infants and toddlers $<36$ months old, children of food insecure households have greater odds, than children of food secure households, of being hospitalized since birth or having fair/poor health. The odds of being hospitalized since birth are almost three times greater for food insecure children (Cook et al, 2004). Children 6 to 16 years old of food insecure households are also significantly more likely to experience more frequent stomachaches and headaches. Along with preschoolers 1 to 
5 years old, the same children are also more significantly likely to have more frequent colds (Alaimo et al, 2001).

Weinreb and associates found that for preschool-aged children (mean age $=4.2$ years old) moderate hunger among children is a significant indicator of health conditions, but severe hunger is not. Severe hunger is a predictor of internalizing problems, decreased coping strategies, and dealing with anxiety (Weinreb et al, 2002).

For the last decade, questions concerning the association of food insecurity and obesity or overweight have arisen. The prevalence of obesity for adults and children has continued to rise over the last several years (Ogden 2006). Since obesity is associated with excess energy intake and food insecurity limits availability of foods, the relationship between the two may appear inaccurate. However, an association between obesity/overweight and food insecurity has been uncovered by various researchers. This paradox was first questioned in 1995 by William Dietz. In the last decade, several studies have assessed the relationship between food insecurity and weight status. The purpose of this study is to use collected information from parents of a group of preschool children in 2 counties in rural West Virginia to evaluate if the same association exists in a rural, low-income area. The information collected includes weight and height measurements of 2 to 6 year old children. The child's caregiver was asked to complete an 18 question survey which was used to evaluate the household's food security status.

Along with evaluating the association between food security status and weight status, other factors possibly associated with the weight status of preschool aged children were evaluated. The children's parents' BMI and age were evaluated along with the parents' education and hours worked per week. 


\section{$\underline{\text { Review of Literature }}$}

\section{Prevalence of Food Insecurity}

Even with various programs to aid in accessibility of food, food insecurity and hunger continue to be of concern across the nation. In 2005, results of the CPS supplement collecting food security information showed that 12.6 million households (11.0 percent) were food insecure. Approximately 13.9 million children (19 percent of all children under 18 years old) were part of a food insecure household. Since 1998, the prevalence of children in food insecure households has remained between 16.9 and 19.7 percent. Even more importantly 0.7 percent of children suffered from hunger due to food insecurity at least once during the year. The prevalence of food insecurity with hunger among children has remained between 0.5 and 0.7 percent since 1999 , statistically unchanged (Nord et al, 2004).

Furthermore, 16.7 percent of households with children under 6 years old experienced food insecurity at least once in 2005. Of these households, 679,000 (3.9 percent of households with children under 6 years old) were food insecure with hunger. The prevalence of food insecurity is seen to be lowest in married-couple families, white non-Hispanic households, higher income households, and families in the Northeast (Nord et al, 2004).

The USDA also provided very useful data pertaining to the prevalence of foods insecurity with and without hunger by state. For state information, data for 2003-2004 were combined. In this two year time frame, 11.4 percent of all U.S. households were food insecure with or without hunger and 3.8 percent were food insecure with hunger. In West Virginia alone, percentages of households experiencing food insecurity with or 
without hunger and food insecurity with hunger were 8.9 and 3.0, respectively (Nord et al, 2004). The prevalence of food insecurity with or without hunger in West Virginia households has decreased over the previous decade. The averages for 1996-1998 and 1999-2001 were 9.5 percent and 10.3 percent, respectively (Nord et al, 2004).

\section{Measurement of Food Insecurity}

The USDA tool that has been used since 1995 as part of the CPS to measure food insecurity is the U.S. Household Foods Security Survey Module. This is an 18 question survey asking questions pertaining to experiences and behaviors that indicate food insecurity. Ten of the questions pertain to the household level and the remaining 8 questions are specific to children in the household (Bickel et al 2000). This same survey was used to measure food security in this study. The USDA has developed codes, or scores, for each question in order to evaluate food security status. Further details on scoring the survey module can be accessed at http://www.fns.usda.gov/fsec/FILES/FSGuide.pdf. The CPS and most studies gaining food security information utilize this particular survey. In 1999, researcher Edward Frongillo concluded that the series of questions are dependable, precise, and accurate in evaluating food insecurity and hunger status.

\section{Definition of overweight}

The CDC has defined overweight and obesity differently for adults and children. To aid in defining overweight, the CDC uses Body Mass Index (BMI), which is a number calculated from the individual's weight and height. In metric measurement, BMI is equal to weight $(\mathrm{kg}) /[\text { height }(\mathrm{m})]^{2}$. For children, BMI is age and sex specific and is normally referred to as BMI-for-age. After calculating a child's BMI, it is usually plotted on a 
CDC growth chart to obtain a percentile ranking. The percentiles are then used to categorize weight status, as the following:

Table 1 Defining weight status of children with BMI percentiles (National Health and Statistics, 2000).

\begin{tabular}{|l|l|}
\hline \multicolumn{1}{|c|}{ Weight Status Category } & \multicolumn{1}{c|}{ Percentile Range } \\
\hline Underweight & Less than the $5^{\text {th }}$ percentile \\
\hline Healthy weight & $5^{\text {th }}$ percentile to less than the $85^{\text {th }}$ percentile \\
\hline At risk of overweight & $85^{\text {th }}$ to less than the $95^{\text {th }}$ percentile \\
\hline Overweight & Equal to or greater than the $95^{\text {th }}$ percentile \\
\hline
\end{tabular}

\section{Prevalence of Overweight}

The National Health and Nutrition Examination Survey (NHANES) is used to collect data pertaining to the overweight and obesity status of the U.S. civilian, noninstitutionalized population. This sample has been used to evaluate the prevalence of overweight in children and also review changes from previous years sampled. In 20032004, 26.2 percent of children aged 2 to 5 years old were at risk for overweight or overweight (BMI-for-age at $85^{\text {th }}$ percentile or higher). More specifically, 13.9 percent of children aged 2 to 5 years old were overweight with BMI-for-age at $95^{\text {th }}$ percentile or higher. After adjusting for age and race/ethnicity, tests showed a significant increase in the prevalence of overweight in children over 1999-2000, 2001-2002, and 2003-2004. In all children aged 2 to 19 years, there was no significant difference in prevalence of overweight between boys and girls (Ogden 2006).

More specifically, the 2004 Pediatric Nutrition Surveillance System (PedNSS) monitored the nutritional status of children taking part in Federally funded health programs. This survey system has the ability to provide information for individual states. All records are from children 5 years old or younger. In 2004, 12.6 percent of the West Virginia children were found to be overweight (BMI-for-age greater than $95^{\text {th }}$ percentile). 
This places West Virginia in the top one-fourth of the United States for overweight children. According to the PedNSS findings, the prevalence of overweight children has increased by 3.8\% from 1995 and 2004 (Polhamus et al, 2006).

\section{Characteristics of McDowell and Mercer counties}

The most recent data for the prevalence of overweight or obesity in individual counties in West Virginia was collected in 1999. Data collected during this study was from McDowell and Mercer counties in southern West Virginia. In 1995-1999, the prevalence of adult obesity in McDowell and Mercer counties were 29 percent (ranked 4th out of 55 counties) and 17 percent (ranked $30^{\text {th }}$ ), respectively. Previous data from 1990-1994 showed an obesity prevalence of 17.3 percent in McDowell county and 16.2 percent in Mercer county (Chaudari et al, 2002).

McDowell and Mercer counties are on the southern border of West Virginia.

Along with the prevalence of overweight and obesity, other characteristics of McDowell and Mercer counties contributed to the choice of using these two particular counties for this study (Vital Health Statistics of West Virginia, 2005).

Table 2 Demographics of McDowell and Mercer counties

\begin{tabular}{|c|c|c|c|}
\hline & McDowell County & Mercer County & \multirow[t]{2}{*}{ West Virginia } \\
\hline & Rank in State & Rank in State & \\
\hline \multirow[t]{2}{*}{ Population, $2005^{\mathrm{a}}$} & 24,726 & 61,589 & \multirow[t]{2}{*}{$1,816,856$} \\
\hline & $30^{\text {th }}$ of 55 counties & $7^{\text {th }}$ of 55 counties & \\
\hline \multirow{2}{*}{$\begin{array}{l}\text { Per Capita Income } \\
\text { Average, } 2004^{\mathrm{b}}\end{array}$} & 17,622 & 24,820 & \multirow[t]{2}{*}{25,792} \\
\hline & $53^{\text {rd }}$ of 55 counties & $13^{\text {th }}$ of 55 counties & \\
\hline $\begin{array}{l}\text { Average Household } \\
\text { Size, } 2004\end{array}$ & 2.42 & 2.33 & 2.4 \\
\hline Average age, 2000 & 40.2 & 40.5 & $40-49$ \\
\hline $\begin{array}{l}\text { 1-4 year old } \\
\text { children, } 2000^{\mathrm{c}}\end{array}$ & 1,113 & 2,968 & 81,629 \\
\hline
\end{tabular}

a Appendix 1

b Appendix 2

c Appendix 3 
The per capita income of McDowell county is less than $96 \%$ of the other counties in West Virginia. Where as, Mercer County's per capita income is 24,820 , which ranks $13^{\text {th }}$ compared to that of other West Virginia counties. McDowell county is more rural than Mercer county. Mercer county has an interstate highway and two state colleges, whereas McDowell county has neither (Workforce, 2006).

\section{Previous studies associating weight with food security status}

The paradox of hunger causing obesity was first questioned in 1995 by William

Dietz. In a case report, he described a case in which a 7-year-old client of a food insecure household was $220 \%$ of her ideal body weight. He proposed that this may be in part due to eating foods with a greater fat content to prevent hunger, during times when there was a lack of money to buy a variety of foods (Dietz 1995). In the last decade, a variety of studies have been conducted to investigate if this paradox is true in various populations.

Food insecure adults are more likely to be obese than the food secure adults. However in the same study, food security was not significantly associated with childhood (ages 2-12 years) overweight (Martin and Ferris, 2007). Parents often attempt to protect their children from harm and discomfort. It appears that this may also be true when families experience a lack of resources to have access to a variety of healthy foods for themselves and their dependents. Women reporting mild or moderate food insecurity, compared to severe food insecurity or totally food secure, are significantly more likely to be overweight (BMI>27.3) (Townsend et al, 2001). In California women, an increased risk of obesity was observed in all levels of food insecurity compared to food secure households (Adams 2003). Within the last several years, there has been an increase in 
studies relating food security status in households with children and the weight status of children and adolescents.

In 2006, Patrick Casey and colleagues analyzed the NHANES data from 19992002. Their report was based on an analysis of food security and overweight status within the previously collected data. Seventeen percent of the children aged 3 to 17 years lived in a household that experienced food insecurity. Almost $30 \%$ of children had a $\mathrm{BMI} \geq 85^{\text {th }}$ percentile for age. Children, aged 3 to 17 years, who lived in a food insecure household were significantly $(\mathrm{p}<0.01)$ more likely to be at risk for overweight $\left(B M I \geq 85^{\text {th }}\right.$ percentile for age to $95^{\text {th }}$ percentile for age) or overweight (BMI $\geq 95^{\text {th }}$ percentile for age), compared to those from food secure households. The data were also analyzed more specifically. Preschool-aged children 3 to 5 years old and boys who live in food insecure households were not significantly more likely to be at risk for overweight, compared to their counterparts who were in food-secure households. Similar results were found with overweight children. Girls and 12 to 17 year old children of food insecure households were significantly more likely to be overweight than those of food secure households. The association between overweight status and food security was not found in any other age group, but the trend in all age groups was for a higher prevalence of overweight children in food insecure households (Casey at al, 2006).

Many children may be protected from food insecurity when other family members are experiencing the consequences. However some children are not protected. When focusing on households in which children do experience the effects of food insecurity (11.2\% of children included), child food security status is significantly associated with the risk of overweight in children ages 3 to 17, both boys and girls, white and Mexican 
American (not black), and children in families with income below the poverty level. As stated, the associations are between food insecurity and at risk for overweight, not overweight. Overweight status was significantly associated with food insecurity in children 12 to 17 years old, girls, and children in families below with income below the poverty level. However, there was no significant association with children aged 3 to 5 years or boys (Casey et al, 2006).

In 1999, a group of 13,500 kindergarten children was measured, weighed, and their BMI was calculated. Researchers used the USDA's Household Food Security Survey Module to question caregivers regarding food security. For 11,400 of the children from the previous data set, these steps were repeated three years later in 2002. Comparisons were made within the group for differences between 1999 and 2002. Food insecurity among the children in kindergarten was seen to have a significant effect on the changes of BMI and weight only among girls. The girls were more likely to have an increase in their BMI and weight between 1999 and 2002. Among the boys, there was an association between food insecurity and BMI and weight, but it was not statistically significant. Along with growth, food insecurity was associated with lower reading scores, mathematics scores, and lower social skills for girls and boys (Jyoti et al, 2005).

Some ethnic groups seem to be affected by food insecurity at different degrees than others. Mexican American children are sometimes more likely to display an association between food security and weight status. In a study of 239 MexicanAmerican families in the state of California, the 12-item Radimer/Cornell food security scale was used to estimate the levels of food insecurity during the last month. Portable scales were used by trained interviewers to weigh and measure the children. Overweight 
was defined as $\mathrm{BMI} \geq 85^{\text {th }}$ percentile for age and obesity was defined as $\mathrm{BMI} \geq 95^{\text {th }}$ percentile for age. The majority of the families reported some level of food insecurity, with only $21 \%$ reporting food secure. Fourteen percent of the children were measured as being overweight and 23\% were obese. Families who reported household food insecurity tended to have the highest average BMI for age and percentage of children who were overweight and obese; however, differences in BMI by food security level were not statistically significant (Kaiser et al, 2002).

The Continuing Survey of Food Intakes by Individuals (CSFII) was a nutrition survey conducted by the USDA in 1994 through 1996. The data from the survey were used to examine the characteristics of children, aged 0 months to 17 years, living in foodinsufficient households, especially in households with low-income. For this study, foodinsufficiency was defined as reports of "often don't have enough to eat" or "sometimes don't have enough to eat". Weight and height was self-reported by the children's caregiver(s). Low-income households were defined as a household with income at or below $130 \%$ of the federal poverty line. This guideline is used as income criteria for several federal assistance programs, such as the Food Stamp Program (Casey et al, 2001).

When compared to the children of food-sufficient, higher-income households, children who are from a food-insufficient, low-income household were significantly more likely to be overweight (BMI percentile greater than the $85^{\text {th }}$ ). However, among the lowincome households food sufficiency did not have a significant relationship with the children's weight status (Casey et al, 2001). 


\section{Purpose of the Study}

There have been few studies that have found a relationship between the weight of children and household food security status. Also, no known studies have been conducted in rural West Virginia. The objectives of this study are:

1) To determine the prevalence of household food insecurity in McDowell and Mercer counties.

2) To determine the prevalence of overweight in 2 to 6 year old children in McDowell and Mercer counties.

3) To quantify the relationship between food insecurity and BMI among preschool-aged children in McDowell and Mercer counties.

4) To quantify the relationship between BMI among preschool-aged children in McDowell and Mercer counties and their parents' BMI, age, education attainment, and hours worked per week.

\section{Methods}

Data collection for this study was conducted in cooperation with the West Virginia University (WVU) Extension Service Family Nutrition Program (FNP) in McDowell and Mercer counties in southern West Virginia. These counties were chosen due to their strong FNP leadership and McDowell county's high prevalence of obesity. Lisa Mitchell, the Family and Consumer Sciences Extension agent, the Nutrition Outreach Instructors in these counties, Dr. Cindy Fitch, recent WVU graduate student Jill Kloss RD, and Melissa Webber collected the data. All parties were trained in appropriate methods for weighing and measuring children. 
Study participants were preschool age (2 to 6 years old) and their parents who are participating in the FNP Head Start Program. Investigators met with the parents to explain the study and received informed consent before enrolling the children in the study (Appendix 4). Approval was granted by the West Virginia University Institutional Review Board for the Protection of Human Subjects (IRB \#15613).

\section{Obtaining demographics}

The sex and birth date of children were provided by the child's parent or caregiver. All children were measured in light clothing and without shoes. Height was measured using a portable stadiometer and weight was measured using an electronic scale. BMI percentiles were calculated using EpiInfo 2000. For the children, BMI percentiles were divided into 3 categories, including: normal weight as less than $85^{\text {th }}$ percentile, at risk for overweight as equal to or greater than $85^{\text {th }}$ percentile but less than the $95^{\text {th }}$ percentile, and overweight as equal to or greater than the $95^{\text {th }}$ percentile.

Age, height, and weight of the mother and father were self reported by caregivers. The weight and height was then used to calculate the parents' BMI. The parents' BMI was divided into similar categories as the children: normal weight as $\mathrm{BMI}<25$, overweight as $25 \leq \mathrm{BMI}>30$, and obese as $\mathrm{BMI} \geq 30$. The children's parents' education level and their hours worked per week were obtained. Further questions obtained the number of adults in the home and who was primarily responsible for purchasing and preparing food (Appendix 5).

\section{Food security analysis}

Caregivers of the children were asked to respond to the Household Food Security Survey module (Appendix 6). In order to determine the food security of the families, 
each response was coded and scored according to previously validated methods (Bickel et al, 2000). Each negative and affirmative response is coded as either 0 or 1, respectively. Each survey participants' total amount of affirmative responses is totaled. Using a chart established by the USDA, the affirmative responses are given either a scale value or a code pertaining to a food security status level. On a continuous scale, fully secure households have a scale value of zero, and the most severe food insecure have a scale value of ten. Categorical status level scores allow each household to be listed as one of four conditions: food secure, food insecure without hunger, food insecure with moderate hunger, or food insecure with severe hunger (Appendix 7). Categories are summarized in Table 3. For analysis, households were listed into two categories - food secure and food insecure (including those with and without hunger).

Table 3 Scoring of food security responses

\begin{tabular}{|c|c|c|l|}
\hline Affirmative & & \multicolumn{2}{|c|}{ Status Level } \\
\cline { 3 - 4 } Responses & Scale Value & Code & \multicolumn{1}{c|}{ Category } \\
\hline $0-2$ & $0.0-2.2$ & 0 & Food Secure \\
\hline $3-7$ & $2.4-4.4$ & 1 & Food Insecure without hunger \\
\hline $8-12$ & $4.7-6.4$ & 2 & Food Insecure with moderate hunger \\
\hline $13-18$ & $6.6-9.3$ & 3 & Food Insecure with severe hunger \\
\hline
\end{tabular}

\section{Statistical analysis}

To evaluate the relationship between household food security status and weight status among the children, a Poisson regression analysis was used. The FREQ Procedure was used to evaluate the relationship between weight status in the children with the parents' BMI, age, and education. Lastly, the GLM Procedure was used to evaluate the association with children's weight status and the hours worked each week by parents. For all analysis, a p-value $\leq 0.05$ indicated significance. 


\section{$\underline{\text { Results }}$}

A total of 201 subjects were included in the analysis. Whites made up $89 \%$ of the subjects, and the remaining 11\% were black. There were 94 males (46.8\%) and 107 females (53.2\%). The average age was 52 months (4 years and 4 months old), with a range of 25.7 to 71.8 months old ( 2 to 6 years old). The characteristics of the children's mothers and fathers are described in Table 4.

Table 4 Characteristics of children's parents

\begin{tabular}{|l|c|c|}
\hline & Mothers & Fathers \\
\hline Age (years) & $\mathrm{n}=190$ & $\mathrm{n}=174$ \\
Less than 20 & $2(1.0 \%)$ & 0 \\
$20-29$ & $90(42.1 \%)$ & $62(35.6 \%)$ \\
$30-39$ & $80(42.1 \%)$ & $87(50 \%)$ \\
$40-49$ & $16(8.4 \%)$ & $20(11.5 \%)$ \\
Greater than 50 & $2(1 \%)$ & $5(2.9 \%)$ \\
\hline Highest level of Education & $\mathrm{n}=192$ & $\mathrm{n}=186$ \\
Less than 12 years & $41(21.4 \%)$ & $44(23.7 \%)$ \\
High school diploma or equivalent & $77(40.1 \%)$ & $90(48.3 \%)$ \\
Some college courses & $47(24.5 \%)$ & $34(18.3 \%)$ \\
College degree & $20(10.4 \%)$ & $12(6.5 \%)$ \\
Graduate degree & $7(3.6 \%)$ & $6(3.2 \%)$ \\
\hline Hours worked per week & $\mathrm{n}=98$ & $\mathrm{n}=113$ \\
\hline & 34.95 hours & 46.79 hours \\
\hline
\end{tabular}

Mean BMI of the preschool subjects was 16.8, with a range from 12.2 to 29 . A normal BMI was seen in $67 \%$ of the children, while $15.5 \%$ and $17.5 \%$ of the children were at-risk-for overweight and overweight, respectively. The mean BMI of mothers $(\mathrm{n}=179)$ was 28.2 , with $30 \%$ being overweight (BMI between greater than 25 but less than 30$)$ and $30 \%$ being obese $(B M I \geq 30)$. The mean BMI of fathers $(n=171)$ was 28.4 , with $39 \%$ being overweight and $29 \%$ being obese. Accordingly, $32 \%$ of fathers' and $40 \%$ of mothers' BMI were within normal limits. 
Seventy-four percent of the children live in households with two adults, and $17 \%$ of the children live in households with only one adult. In $85 \%$ of the households mothers are primarily responsible for purchasing the food, and $85 \%$ of mothers were also responsible for preparing the foods.

Of the 194 participants responding to the food security survey, 144 households (74.2\%) were found to be food secure during the previous year. Of the remaining 50 households (25.8\%) who reported food insecurity, twelve (6.2\%) experienced moderate hunger and one household ( $0.5 \%)$ experienced severe hunger due to food insecurity.

The association between household food security status and children's BMI $\geq$ $85 \%$ percentile for age was statistically significant $(\mathrm{p}<0.1)$ (Table 5$)$. The child's gender, age, and ethnicity had no statistically significant association with the level of household food security.

Table 5 Children's BMI categories in households experiencing various levels of food security

\begin{tabular}{|l|c|c|c|c|}
\hline & $\begin{array}{c}\text { Normal } \\
\text { weight }\end{array}$ & $\begin{array}{c}\text { At-risk-for } \\
\text { overweight }\end{array}$ & Overweight & Total \\
\hline Food secure & 101 & 22 & 21 & 144 \\
\hline $\begin{array}{l}\text { Food insecure } \\
\text { without hunger }\end{array}$ & 22 & 5 & 10 & 37 \\
\hline $\begin{array}{l}\text { Food insecure with } \\
\text { moderate hunger }\end{array}$ & 6 & 3 & 3 & 12 \\
\hline $\begin{array}{l}\text { Food insecure with } \\
\text { severe hunger }\end{array}$ & 1 & 0 & 0 & 1 \\
\hline Total & 130 & 30 & 34 & 194 \\
\hline
\end{tabular}

The parents' age was not statistically associated with the children's BMI. A significant positive association was present between the BMI of mothers and both boys and girls ( $\mathrm{p}=0.02)$. Father's BMI was only significantly associated with girls' BMI $(\mathrm{p}=0.03)$. Father's highest education attainment had a significant association with the 
boys' BMI ( $\mathrm{p}=0.02)$. Mom's education attainment only had a tendency to be associated with the child's BMI $(\mathrm{p}=0.1)$. The number of hours worked by either parent and the number of adults in the household had no significant relationship with child's BMI.

\section{Discussion}

The aim of this study was to determine various factors that may be associated with child's BMI. Household demographics were also evaluated in the two studied counties in West Virginia. Compared to the 2004 PedNSS results for 1 to 5 year old children in West Virginia, this study found a greater prevalence of overweight in preschool children (aged 2 to 6 years) in McDowell and Mercer counties (Polhamus et al, 2006). Among the adults, the prevalence of obesity in the studied sample was similar to the 1999 prevalence of $29 \%$ in McDowell county and higher than the $17 \%$ prevalence in Mercer county (Chaudari et al, 2002).

The results show that children who are overweight are more likely to be in a household experiencing food insecurity, than children who are of a normal weight. Few studies have seen a similar relationship. The results are somewhat in agreement with Casey and associates (2006). In their study comparing children aged 3 to 17 years, an association existed between food insecurity and risk of being overweight or greater (BMI percentile $\geq 85^{\text {th }}$ ) and being overweight (BMI $\geq 95^{\text {th }}$ percentile). However, when they evaluated just the children aged 3 to 5 years, there was no significant association with weight and household food security status. There was only a correlation among children being at risk of overweight or greater among children who have specifically experienced food the effects of food insecurity. These children are not protected from the effects of food insecurity, unlike what some researchers have hypothesized. 
The study of Mexican-American preschool age children in California showed an similar increase in percent of overweight among children of food insecure households, however their results were not significant. Trained interviewers obtained weight and height measurements from the children. The 12 -item Radimer/Cornell food security scale was used instead of the 18 -item USDA Food Security Module. This was used in order for the researchers to compare to studies in other similar populations and to reduce burden on participants. Due to the use of different survey models, the two studies may not be equally comparable.

The significant correlation with weight and food security status Jyoti and colleagues used longitudinal data from 1998 and 2001 to test how food security status relates to changes in the BMI of children. The children were in kindergarten in 1998 and in $3^{\text {rd }}$ grade in 2001. In 1998 and 2001, the parents were interviewed to obtain the child's weight and height, and the USDA food security module was used to collect food security data. Their results found that girls, in a household experiencing food insecurity in the past year, had a significant change in BMI over the three years. Interviewers did not measure the children. Instead, parents were asked to respond to questions concerning the weight and height of their children (Jyoti et al, 2005). Whereas, in our study trained interviewers weighed and measured each child.

The significant findings that mothers' BMI was positively related to child BMI suggests that other family or household factors may have a strong association with the child's weight. There was also a significant positive relationship between fathers' BMI and girl's BMI, however not the boys' BMI. This relationship seems to suggest a genetic relationship between the BMI of parents and their child(ren). Further research 
controlling for other environmental factors would be helpful in describing this relationship and describing if it is in fact due to genetics.

The only significant finding associating the education attainment of parents and child BMI was that the father's education was positively related to the boys' BMI. The mother's education attainment only had a non-significant tendency to be related to the child's BMI. The relationship between the child's BMI and the parents' education level is perplexing. No other known research exists which evaluated this relationship. Due to our significant finding, the topic should be studied further to attempt to find a reason for the association.

Some factors did exist that may have skewed the results of this study. Other than the child's height and weight, data were self-reported by parents (or other caregivers). Limitations always exist with self-reported data. The parents may be ashamed or reluctant to honestly answer questions regarding food purchasing or eating habits for them or their children. When asked to report their weight and height, they may also be reluctant. Some respondents may also not have known the actual weight and height of the child's other parent, if they were not present. Also when asked how many hours each parent worked per week, several respondents did not give a complete answer.

\section{Conclusion}

The prevalence of overweight and obesity among children and adults continue to increase. Some changes need to be made to lower this increasing prevalence. This study of children aged 2 to 6 years old in rural, southern West Virginia showed there are factors among the household or parents that are significantly related to the child's likelihood of being at risk-for-overweight or overweight. Using these findings, future researchers 
should use other controls to evaluate if there are any confounding factors leading to these associations.

The relationship between food insecurity and the increased prevalence of overweight is a perplexing issue. Many suggestions for this bizarre association exist. In 1995, William Dietz was first to question this relationship. As he suggested, those with limited funds to purchase foods at certain times of the month may use foods of high fat or high calorie content to subside feelings of hunger. These high fat and high calorie foods are often not high in other nutrients, vitamins, and minerals. Along with unnecessary weight gain, their increased intake and limited intake of nutrient-dense foods can later lead to other negative health consequences, such as cardiovascular disease and diabetes.

Federally programs such as the Food Stamp Program (FSP) and Women, Infants, and Children (WIC) provide food supplements to many of these low-income families. The funds or supplemental food packages are typically distributed or available to use at a particular time of the month. Once these food supplies are depleted, the family members may have to rely on other methods to fulfill their hunger cues. This includes the previously mentioned high-fat and high-calorie foods.

Families living in rural, low-income areas, such as McDowell and Mercer counties, are also often limited in their choices of supermarkets and grocery stores. The stores that are available may also have a limited variety or amount of healthful foods such as fresh fruits and vegetables. Along with limited available, the more expensive pricing of fresh fruits and vegetables, low-fat meat products, and whole grain foods limit some families' ability to purchase healthful foods. Therefore, there is a great need for the 
continuation of the federal, state, and local programs that allow families to purchase and consume healthy food options.

The significant relationship between increased parents' BMI and increased child's weight status surfaces some concerns which should be further researched. This research should evaluate if this association is due to genetics or environmental factors. Education for the parent and child can potentially have an effect on decreasing this association.

With an increase in technology for entertainment and an increase in parents' concern with the safety of their community, many children do not have adequate time or space to play outside.

Body weight plays an important role in everyone's life. Those who are overweight are more likely to have other on-going medical concerns and consequences. It is very important to continue to research the causes of obesity and unwanted weight gain. Along with this research, programs to continue to aid in weight loss and nutrition education can aid in increasing everyone's health. 


\section{References:}

Adams EJ, Grummer-Strawn L, Chavez G. Food insecurity is associated with increased risk of obesity in California women. J Nutr 2003; 133: 1070-1074.

Alaimo K, Olson CM, Frongillo EA, Briefel RR. Food insufficiency, family income, and health in US preschool and school-aged children. Am J Public Health 2001; 91: 781-786.

Anderson S. Core indicators of nutritional state for difficult to sample populations. $J$ Nutr. 1990; 102: 1559-1660.

Bickel G, Nord M, Price C, Hamilton W, Cook J. Guide to Measuring Household Food Security, Revised 2000. Alexandria, VA: Food and Nutrition Service, US Dept of Agriculture; 2000.

Casey PH, Szeto K, Lensing S, Bogle M, Weber J. Children in food-insufficient, low-income families. Prevalence, Health and Nutrition Status. Arch Pediatr Adolesc Med. 2001; 155:508-514.

Casey PH, Simpson PM, Gossett JM, Bogle ML, Champagne CM, Connell C, Harsha D, McCabe-Sellers B, Robbins JM, Stuff JE, Weber J. The association of child and household food insecurity with childhood overweight status. Pediatrics. 2006; 118;1406-1413. http://www.pediatrics.org/cgi/content/full/118/5/e1406

Center for Disease Control and Prevention. BMI - About BMI for Children and Teens. Available at http://www.cdc.gov/nccdphp/dnpa/bmi/childrens_BMI/about_childrens_BMI.htm. Accessed on September 152006.

Chaudhari A, Doria J, Kennedy JD, Kink F, Leonard TN, Light T, Simmons P. Obesity: Facts, Figres, Guidelines. Department of Health and Human Resources. 2006. Available at http://www.wvdhhr.org/bph/oehp/obesity/default.htm.

Cook JT, Frank DA, Berkowitz C, Black MM, Casey PH, Cutts DB, Meyers AF, Zaldivar N, Skalicky A, Levenson S, Heeren T, Nord M. Food insecurity is associated with adverse health outcomes among human infants and toddlers. J Nutr. 2004; 134:1432-1438.

Dietz W. Does hunger cause obesity? Pediatrics 1995; 95:766-767.

Emmons, L. Food procurement and the nutritional adequacy of diets in low-income families. J Am Diet Assoc. 1986;86:1684-1693

Frongillo EA. Validation of measures of food insecurity and hunger. J Nutr 1999; 129:506S-509S. 
Johnson-Down L, O’Loughin J, Koski KG, Gray-Donald K. High prevalence of obesity in low income and multiethnic school children: a diet and physical activity assessment. J Nutr. 1997; 127:2310-2315.

Jyoti DF, Frongillo EA, Jones SJ. Food insecurity affects school children's academic performance, weight gain, and social skills. J Nutr. 2005;135:2831-2839.

Kaiser LL, Melgar-Quinonez, Lamp CL, Johns MC, Sutherlin JM, Harwood JO. Food security and nutritional outcomes of preschool-age Mexican-American children. J Am Diet Assoc. 2002; 102:924-929.

Kendall A, Olson CM, Frongillo EA. Relationship of hunger and food insecurity to food availability and consumption. J Am Diet Assoc. 1996; 96:1019-1024.

Martin KS, Ferris AM. Food insecurity and gender are risk factors for obesity. $J$ Nutr Educ Behav. 2007; 39:31-36

Matheson DM, Varady J, Varady A, Killen JD. Household food security and nutritional status of Hispanic children in the fifth grade. Am J Clin Nutr. 2002; $76: 210-217$.

National Center for Health Statistics. 2000 CDC Growth Charts: United States. 2000. Available at http://www.cdc.gov/nchs/about/major/nhanes/growthcharts/background.htm. Accessed Februrary 12, 2005.

Nord M, Andrews M, Carlson S. Household Food Security in the United States, 2005. (ERR-11). Alexandria, VA: Food and Rural Economics Division, Economic Research Service, US Department of Agriculture; 2005. Available at http://www.ers.usda.gov/publications/err11/err11.pdf. Accessed July 25, 2006.

Ogden CL, Carroll MD, Curtin LR, McDowell MA, Tabak CJ, Flegal KM. Prevalence of overweight and obesity in the United States, 1999-2004. JAMA. 2006; 295:1549-1555.

Polhamus B, Thompson D, Dalenius K, Borland E, Smith B, Grummer-Strawn L. Pediatric Nutrition Surveillance 2004 Report. Atlanta: U.S. Department of Health and Human Services, Centers for Disease Control and Prevention; 2006.

Townsend MS, Peerson J, Love B, Achterberg C, Murphy SP. Food insecurity is positively related to overweight in women. J Nutr. 2001; 131:1738-1745.

Thoenen E, Wright JG. Obesity: Facts, Figures, Guidelines. 2002. Available at http://www.wvdhhr.org/bph/oehp/obesity/contents.htm. Accessed February 12, 2005. 
Vital Health Statistics of West Virginia, 2005, West Virginia Bureau for Public Health, Office of Epidemiology and Health Promotion, Health Statistics Center, May 2007.

Weinreb L, Wehler C, Perloff J, Scott R, Hosmer D, Sagor L, Gundersen C. Hunger: its impact on children's health and mental health. Pediatrics 2002;110: e1. http://ww.pediatrics.org/cgi/content/full/110/4/e4l.

WORKFORCE West Virginia Research, Information and Analysis. 2006. Accessed at http://www.wvbep.org/bep/LMI/CNTYPROF/ 
$\underline{\text { Appendix } 1}$

West Virginia Population, 2004 and 2005

Table 1

\begin{tabular}{|c|c|c|c|c|c|}
\hline County & $2004^{*}$ & $2005^{*}$ & County & $2004^{*}$ & $2005^{*}$ \\
\hline Barbour & 15,476 & 15,689 & Monongalia & 83,918 & 84,386 \\
\hline Berkeley & 89,362 & 93,394 & Monroe & 13,568 & 13,507 \\
\hline Boone & 25,721 & 25,703 & Morgan & 15,810 & 16,022 \\
\hline Braxton & 14,950 & 14,851 & Nicholas & 26,276 & 26,464 \\
\hline Brooke & 24,785 & 24,515 & Ohio & 45,410 & 45,112 \\
\hline Cabell & 94,801 & 94,031 & Pendleton & 7,897 & 7,844 \\
\hline Calhoun & 7,415 & 7,387 & Pleasants & 7,441 & 7,376 \\
\hline Clay & 10,424 & 10,356 & Pocahontas & 8,995 & 8,851 \\
\hline Doddridge & 7,418 & 7,476 & Preston & 29,856 & 30,115 \\
\hline Fayette & 47,049 & 46,823 & Putnam & 53,836 & 54,443 \\
\hline Gilmer & 6,982 & 6,950 & Raleigh & 79,175 & 79,167 \\
\hline Grant & $\mathbf{1 1 , 5 3 7}$ & 11,673 & Randolph & 28,495 & 28,571 \\
\hline Greenbrier & 34,886 & 35,027 & Ritchie & 10,486 & 10,540 \\
\hline Hampshire & 21,542 & 22,025 & Roane & 15,359 & 15,407 \\
\hline Hancock & $\mathbf{3 1 , 5 0 7}$ & $\mathbf{3 1}, \mathbf{3 5 0}$ & Summers & 13,809 & 13,740 \\
\hline Hardy & 13,209 & 13,287 & Taylor & 16,202 & 16,291 \\
\hline Harrison & 68,303 & 68,369 & Tucker & 7,046 & 6,943 \\
\hline Jackson & 28,477 & 28,403 & Tyler & 9,365 & 9,340 \\
\hline Jefferson & 47,663 & 49,206 & Upshur & 23,996 & 23,712 \\
\hline Kanawha & 195,218 & 193,559 & Wayne & 42,515 & 42,091 \\
\hline Lewis & 17,132 & 17,199 & Webster & 9,849 & 9,804 \\
\hline Lincoln & 22,564 & 22,374 & Wetzel & 17,048 & 17,117 \\
\hline Logan & 36,502 & 36,237 & Wirt & 5,835 & 5,896 \\
\hline McDowell & 24,726 & 24,273 & Wood & 87,100 & 87,047 \\
\hline Marion & 56,453 & $\mathbf{5 6 , 5 0 9}$ & Wyoming & 24,698 & 24,479 \\
\hline Marshall & 34,722 & $\mathbf{3 4 , 3 3 7}$ & & & \\
\hline Mason & 25,941 & 25,761 & & & \\
\hline Mercer & 62,070 & 61,589 & Total & $1,815,354$ & $1,816,856$ \\
\hline Mineral & 27,145 & 27,028 & & & \\
\hline Mingo & 27,389 & 27,210 & & & \\
\hline
\end{tabular}

( Population estimates from U.S. Bureau of the Census

West Virginia Bureau for Public Health Health Statistics Center, 2007 


\section{$\underline{\text { Appendix } 2}$}

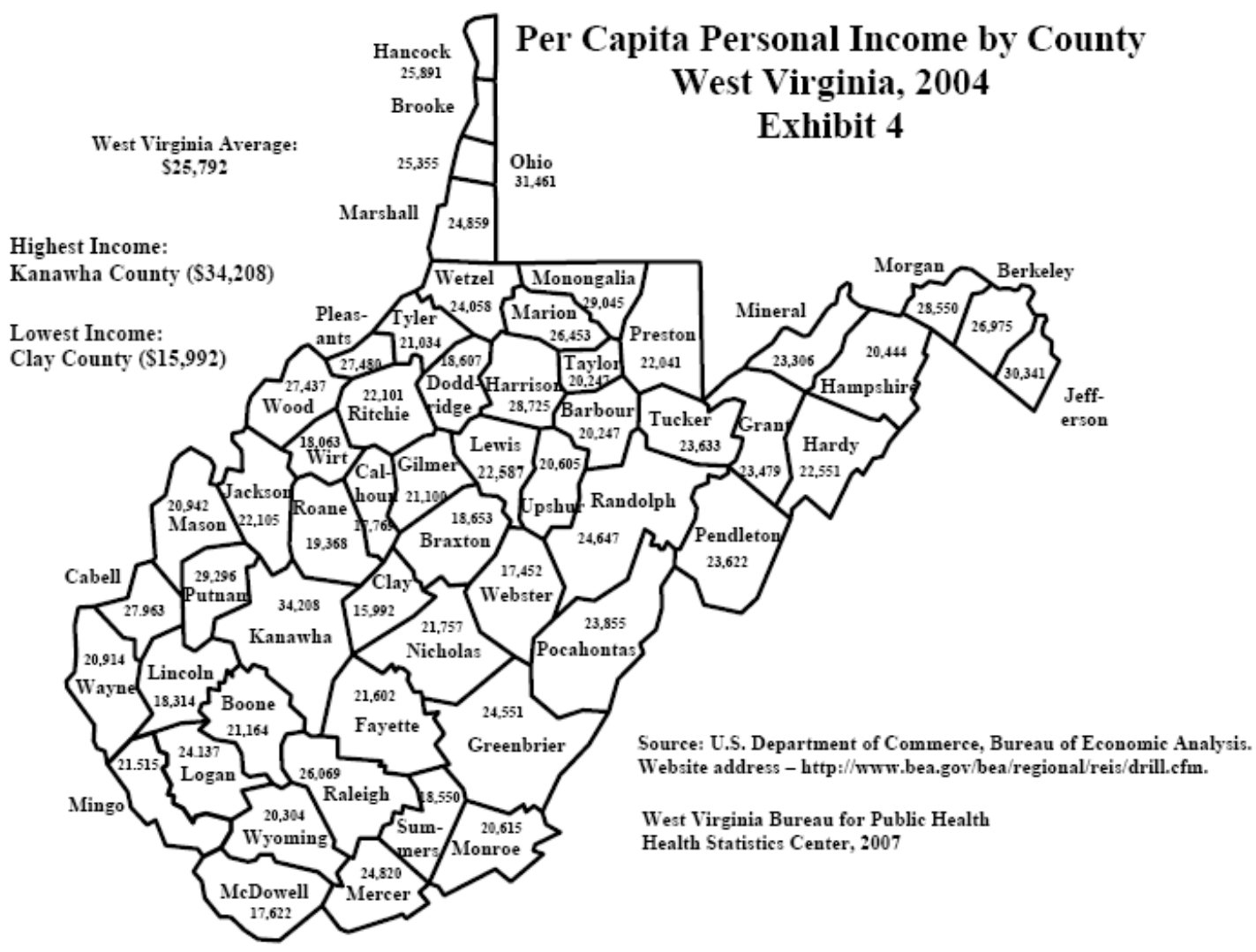




\section{$\underline{\text { Appendix } 3}$}

\section{Age Group Distribution by County \\ West Virginia Population, 2000 Both Genders \\ Table 3}

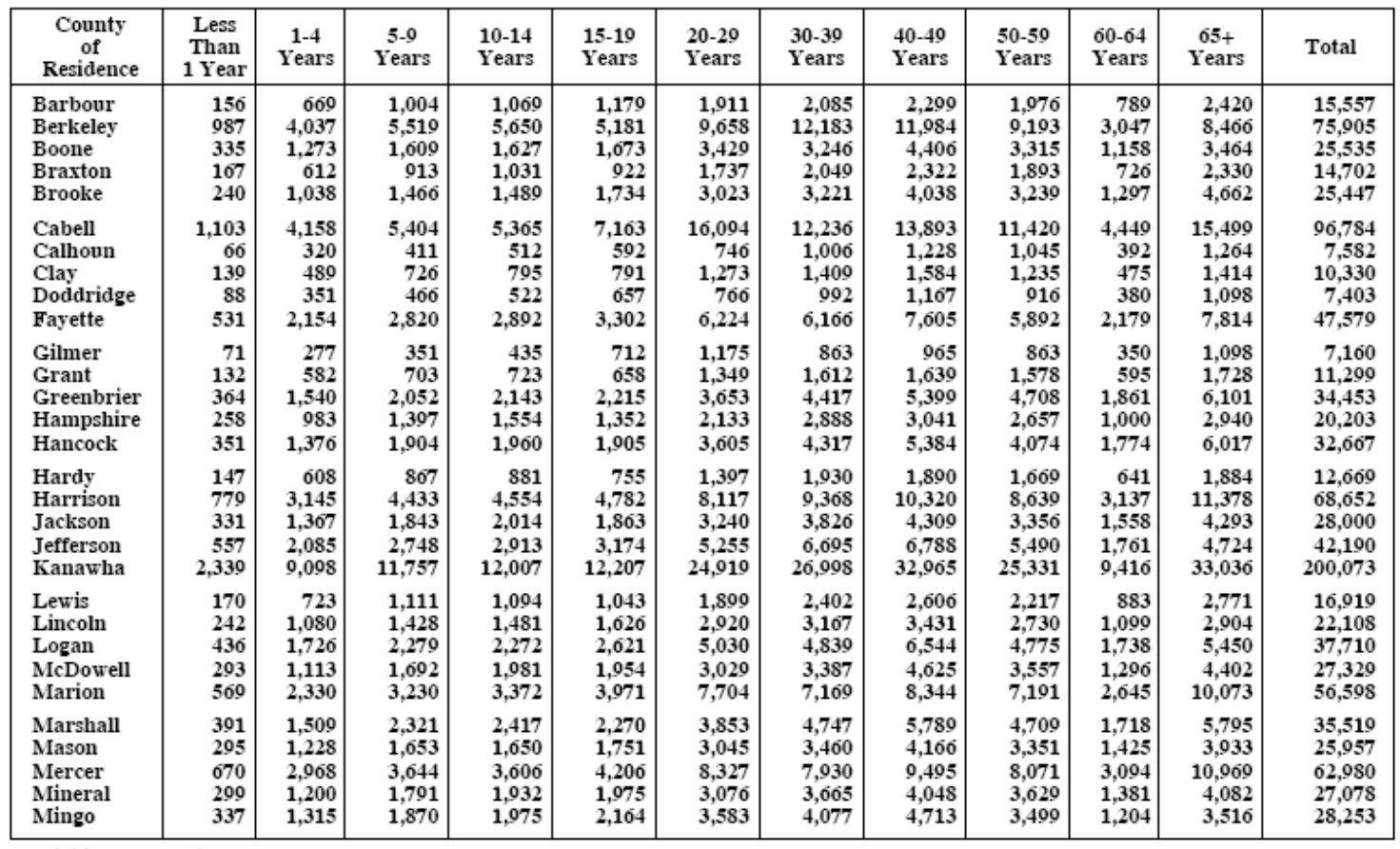

Wet Virginia Doreas for Public Healt 


\section{Age Group Distribution by County \\ West Virginia Population, 2000 \\ Both Genders \\ Table 3 (continued)}

\begin{tabular}{|c|c|c|c|c|c|c|c|c|c|c|c|c|}
\hline $\begin{array}{c}\text { County } \\
\text { of } \\
\text { Residence }\end{array}$ & $\begin{array}{c}\text { Less } \\
\text { Than } \\
1 \text { Year }\end{array}$ & $\begin{array}{c}1-4 \\
\text { Years }\end{array}$ & $\begin{array}{c}5-9 \\
\text { Years }\end{array}$ & $\begin{array}{l}10-14 \\
\text { Years }\end{array}$ & $\begin{array}{l}15-19 \\
\text { Years }\end{array}$ & $\begin{array}{l}20-29 \\
\text { Years }\end{array}$ & $\begin{array}{l}30-39 \\
\text { Years }\end{array}$ & $\begin{array}{l}40-49 \\
\text { Years }\end{array}$ & $\begin{array}{l}50-59 \\
\text { Years }\end{array}$ & $\begin{array}{l}60-64 \\
\text { Years }\end{array}$ & $\begin{array}{c}65+ \\
\text { Years }\end{array}$ & Total \\
\hline Monongalia & 806 & 3,238 & 4,156 & 4,157 & 8,274 & 19,846 & 10,086 & 11,077 & 8,165 & 2,696 & 8,765 & 81,800 \\
\hline Mon & 14 & & 00 & 894 & 842 & 1,848 & 2,266 & 2,246 & 2,007 & 715 & 2,242 & 14,583 \\
\hline Morgan & 186 & 710 & 962 & 934 & 827 & 1,574 & 2,096 & 2,345 & 1,998 & 827 & 2,475 & 14,943 \\
\hline Nicholas & 276 & 1,163 & 1,654 & 1,008 & 1,857 & 3,046 & 3,628 & 4,285 & 3,411 & 1,360 & 3,974 & 26,562 \\
\hline Ohio & 476 & 1,973 & 2,769 & 3,009 & 3,510 & 5,780 & 5,752 & 7,466 & 5,602 & 2,181 & 8,900 & 47,427 \\
\hline Pendleton & 80 & 360 & 503 & 545 & 470 & 923 & 1,089 & 1,274 & 1,034 & 458 & 1,460 & 8,190 \\
\hline Plea & 9 & 351 & 514 & 494 & 507 & 867 & & 11 & 950 & 338 & 1,122 & 7,514 \\
\hline Poca & 82 & 370 & 526 & 501 & 495 & 981 & 1,257 & 1,429 & 1,295 & 528 & 1,577 & 9,131 \\
\hline Preston & 300 & 1,325 & 1,815 & 2,049 & 2,109 & 3,287 & 4,069 & 4,697 & $\mathbf{3 , 7 7 7}$ & 1,421 & 4,386 & 29,334 \\
\hline Putnam & 638 & 2,726 & $\mathbf{3 , 5 8 2}$ & 3,769 & 3,414 & 5,859 & 7,886 & 8,818 & 6,709 & 2,227 & 5,061 & $\mathbf{5 1 , 5 8 9}$ \\
\hline Raleigh & 890 & 3,458 & 4,681 & 4,889 & 5,060 & 10,706 & 10,514 & 13,065 & 10,130 & 3,618 & 12,200 & 79,220 \\
\hline Ran & 310 & 1,168 & 1,803 & 1,850 & 1,883 & 3,511 & 4,135 & 4,252 & 3,700 & 1,376 & 4,265 & 28,262 \\
\hline Ritcl & 92 & 472 & 663 & 684 & 723 & 1,126 & 1,425 & 1,631 & 1,379 & 572 & 1,576 & 10,343 \\
\hline Roan & 185 & 698 & 918 & 1,071 & 1,157 & 1,821 & 2,000 & 2,461 & 2,020 & 833 & 2,282 & 15,440 \\
\hline Sun & 102 & 502 & 757 & 761 & 856 & 1,365 & 1,549 & 2,043 & 1,743 & 728 & 2,593 & 12,999 \\
\hline Tayl & 180 & 684 & 1,002 & 1,132 & 1,082 & 1,851 & 2,342 & 2,565 & 1,965 & 747 & 2,539 & $16,08 \mathrm{~s}$ \\
\hline & & 283 & 447 & 428 & 485 & 702 & & & & 458 & & $\mathbf{7 , 3 2 1}$ \\
\hline Tyl & 110 & 393 & 607 & 690 & 610 & 975 & 1,268 & 1,523 & 1,291 & 528 & 1,579 & 9,592 \\
\hline Ups & 226 & 1,022 & 1,493 & 1.520 & 2,071 & 3,228 & 2,945 & 3,446 & 2,876 & 1,119 & 3,449 & 23,404 \\
\hline Wayne & 516 & 1,955 & 2,813 & 2,904 & 2,993 & 5,386 & 5,882 & 6,292 & 5,527 & 2,224 & 6,411 & 42,903 \\
\hline Webster & 91 & 409 & 635 & 670 & 665 & 1,105 & 1,222 & 1,579 & 1,347 & 514 & 1,482 & 9,710 \\
\hline & 184 & 823 & 1,146 & 1,249 & 1,210 & 1,761 & 2,348 & 2,699 & 2,392 & 1,011 & 2,861 & 17,693 \\
\hline Wirt & 53 & 276 & 417 & 445 & 447 & 630 & 894 & 903 & 717 & 328 & 763 & 5,873 \\
\hline Woo & 943 & 4,146 & 5,597 & 5,042 & 5,724 & 10,179 & 12,383 & 13,642 & 11,458 & 4,364 & 13,608 & 87,980 \\
\hline Wyoming & 286 & 1,181 & 1,478 & 1,654 & 1,792 & 3,159 & 3,253 & 4,648 & 3,410 & 1,261 & 3,586 & 25,708 \\
\hline Total & 20,176 & 81,620 & 111,150 & 116,182 & 125,578 & 233,086 & 245,333 & 283,662 & 228,153 & 85,900 & 276,895 & $1,808,34$ \\
\hline
\end{tabular}

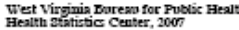




\section{$\underline{\text { Appendix } 4}$}

\section{Parental or Guardian Consent and Information Form}

Factors Affecting Intake, Growth, and Body Mass Index of Preschool Children

\section{Introduction}

I, , have been asked to allow my child to participate in a research study that examines the factors that affect intake and growth among children aged three to five years. Cindy Fitch, Ph.D., RD who is conducting this research at West Virginia University has explained the study to me. I understand that the money to pay for this study is being provided by the United States Department of Agriculture.

\section{Purposes of the Study}

I understand that the purpose of this study is to learn more about factors that influence intake, growth, and weight gain of children aged three to five years.

\section{Description of Procedures}

This study will be performed at a church, day care, or Head Start center that my child attends or at the county WVU Extension office. My child will be weighed and measured and I will be asked to report everything he/she eats or drinks for two 24-hour periods. I will also be asked to fill out a series of questionnaires. I understand that it will take about 1 hour of my time for the diet history and questionnaires. I have been given an opportunity to examine the questionnaires. Approximately 300 children will be enrolled in this study.

\section{Benefits}

I understand that this study is not expected to be of direct benefit to my child but the knowledge gained may be of benefit to others.

\section{Risks and Discomforts}

There are no known or expected risks from participating in this study.

\section{Financial Considerations}

I understand that there is no cost to me for participation in this study and I will receive a grocery store gift certificate for $\$ 20.00$ as a token of appreciation for my time. 
Factors Affecting Intake, Growth, and Body Mass Index of Preschool Children

\section{Alternatives}

I understand that not participating in this study is an alternative that is open to me.

\section{Contact Persons}

For more information about this research I can contact Dr. Cindy Fitch at 304-293-3402, extension 1768. For information regarding my child's rights as a research subject, I may contact the Executive Secretary of the Institutional Review Board at 304-293-7073.

\section{Confidentiality}

I understand that any information obtained as a result of my child's participation in this research will be kept as confidential as legally possible. I understand that these research records, just like hospital records, may be subpoenaed by court order or may be inspected by federal regulatory authorities. My name or that of my child or any information from which we might be identified may not be published without my consent.

\section{Voluntary Participation}

Participation in this study is voluntary. If my child participates, I may withdraw my child from this study at any time. Refusal to participate or withdrawal will involve no penalty or loss of benefits for my child or me. I have been given the opportunity to ask questions about the research, and I have received answers concerning areas I did not understand. Upon signing this form, I will receive a copy.

I willingly consent to my child's participation in this research.

Signature of Parent of Guardian

Date

Time

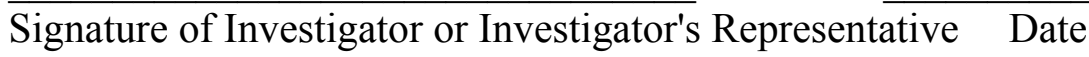

Time 


\section{Appendix 5}

\section{Parent Information Form}

ID Number

Mother's Age

Less than 20 years

20 to 29 years

30 to 39 years

40 to 49 years

50 years or greater

\section{Mother's height}

\section{Mother's weight}

Number of adults in home

Who is primarily responsible for food purchases?

Food preparation?

\section{Mother's education level}

Less than 12 years

High school diploma or equivalent

Some college courses

College degree

Graduate degree

\section{Mother's Occupation}

Number of hours worked per week

\section{Father's Age}

Less than 20 years

20 to 29 years

30 to 39 years

40 to 49 years

50 years or greater

Father's height

Father's weight

How many hours per day does your child spend watching television or videos? Playing video or computer games?

Does he/she have a television in his/her room?

Father's education level

Less than 12 years

High school diploma or equivalent Some college courses

College degree

Graduate degree

Hours worked per week

\section{Father's Occupation}




\section{Appendix 6}

\section{Household Food Security Survey}

These questions are about the food eaten in your household in the last 12 months, since of last year, and whether you were able to afford the food you need.

1. Which of these statements best describes the food eaten in your household in the last 12 months?
a. Enough of the kinds of food we want to eat
b. Enough but not always the kinds of food we want
c. Sometimes not enough to eat
d. Often not enough
e. No answer

(1a) Here are some reasons why people don't always have enough to eat. For each one, please indicate if that is a reason why YOU don't always have enough to eat. Circle all that apply and leave it blank if it does not apply to your household
a. Not enough money for food
b. Not enough time for shopping or cooking
c. Too hard to get to the store
d. I am on a diet
e. No working stove available
f. Not able to cook or eat because of health problems
This question does not apply to my family 
(1b) Here are some reasons why people don't always have the quality or variety of food they want. For each one, please indicate if that is a reason why YOU don't always have the kinds of food you want to eat. Circle all that apply.
a. Not enough money for food
b. Kinds of food we want not available
c. Not enough time for shopping or cooking
d. Too hard to get to the store
e. I am on a special diet

This question does not apply to my family

The following statements are some that people have made about their food situation. For each statement, please indicate whether the statement was often true, sometimes true, or never true for your household in the last 12 months, that is, since last year at this time. Please circle your answer.

2. "We worried whether our food would run out before we got money to buy more".
a. Often true
b. Sometimes true
c. Never true
d. Don't know

3. "The food that we bought just didn't last, and we didn't have money to get more".
a. Often true
b. Sometimes true
c. Never true
d. Don't know 
4. "We couldn't afford to eat balanced meals".
a. Often true
b. Sometimes true
c. Never true
d. Don't know

5. "We relied on only a few kinds of low-cost food to feed the children because we were running out of money to buy food".
a. Often true
b. Sometimes true
c. Never true
d. Don't know

6. "We couldn't feed the children a balanced meal because we couldn't afford that".
a. Often true
b. Sometimes true
c. Never true
d. Don't know

7. "My child was not eating enough because we just couldn't afford enough food".
a. Often true
b. Sometimes true
c. Never true
d. Don't know

8. In the last 12 months, since this time last year, did you or other adults in your household ever cut the size of your meals or skip meals because there wasn't enough money for food?
Yes
No Don't know 
If yes, how often did this happen?
a. Almost every month
b. Some months but not every month
c. Only 1 or 2 months
d. Don't know

9. In the last 12 months, did you ever eat less than you felt you should because there wasn't enough money to buy food?

Yes No Don't know

10. In the last 12 months, were you ever hungry but didn't eat because you couldn't afford enough food

Yes No Don't know

11. In the last 12 months, did you lose weight because you didn't have enough money for food?

Yes No Don't know

12. In the last 12 months, did you or other adults in your household ever not eat for a whole day because there wasn't enough money for food?

Yes No Don't know

If yes, how often did this happen?
a. Almost every month
b. Some months but not every month
c. Only 1 or 2 months
d. Don't know 
The next questions are about children living in the household who are under 18 years of age.

13. In the last 12 months, since this time last year, did you ever cut the size of any of the children's meals because there wasn't enough money for food?

Yes No Don't know

14. In the last 12 months, did any of the children ever skip meals because there wasn't enough money for food?

Yes No Don't know

If yes, how often did this happen?

a. Almost every month

b. Some months but not every month

c. Only 1 or 2 months

d. Don't know

15. In the last 12 months were the children ever hungry but you just couldn't afford more food?

Yes No Don't know

16. In the last 12 months, did any of the children ever not eat for a whole day because there wasn't enough money for food?

Yes No Don't know

Thank you for participating in this study. 


\section{$\underline{\text { Appendix } 7}$}

Exhibit 3-3

HOUSEHOLDS WITH COMPLETE RESPONSES:

FOOD SECURITY SCALE VALUES AND STATUS LEVELS CORRESPONDING TO NUMBER OF AFFIRMATIVE RESPONSES

\begin{tabular}{|c|c|c|c|c|}
\hline \multicolumn{2}{|c|}{$\begin{array}{c}\text { Number of Affirmative } \\
\text { Responses: }\end{array}$} & \multirow{2}{*}{$\begin{array}{c}1998 \text { Food } \\
\text { Security } \\
\text { Scale Values }\end{array}$} & \multicolumn{2}{|c|}{ Food Security Status Level } \\
\hline $\begin{array}{c}\text { (Out of 18) } \\
\text { Households } \\
\text { With } \\
\text { Children }\end{array}$ & $\begin{array}{c}\text { (Out of 10) } \\
\text { Households } \\
\text { Without } \\
\text { Children }\end{array}$ & & Code & Category \\
\hline $\begin{array}{l}0 \\
1 \\
2\end{array}$ & $\begin{array}{l}0 \\
1 \\
2 \\
\end{array}$ & $\begin{array}{l}0.0 \\
1.0 \\
1.2 \\
1.8 \\
2.2\end{array}$ & 0 & Food Secure \\
\hline $\begin{array}{l}3 \\
4 \\
5 \\
6 \\
7\end{array}$ & $\begin{array}{l}3 \\
4 \\
5 \\
\end{array}$ & $\begin{array}{l}2.4 \\
3.0 \\
3.0 \\
3.4 \\
3.7 \\
3.9 \\
4.3 \\
4.4 \\
\end{array}$ & 1 & $\begin{array}{c}\text { Food Insecure Without } \\
\text { Hunger }\end{array}$ \\
\hline $\begin{array}{c}8 \\
\\
9 \\
10 \\
\\
11 \\
12\end{array}$ & $\begin{array}{l}6 \\
7 \\
8\end{array}$ & $\begin{array}{l}4.7 \\
5.0 \\
5.1 \\
5.5 \\
5.7 \\
5.9 \\
6.3 \\
6.4\end{array}$ & 2 & $\begin{array}{c}\text { Food Insecure With Hunger, } \\
\text { Moderate }\end{array}$ \\
\hline $\begin{array}{l}13 \\
14 \\
15 \\
\\
16 \\
17 \\
18\end{array}$ & $\begin{array}{l}9 \\
10\end{array}$ & $\begin{array}{l}6.6 \\
7.0 \\
7.2 \\
7.4 \\
7.9 \\
8.0 \\
8.7 \\
9.3\end{array}$ & 3 & $\begin{array}{c}\text { Food Insecure With Hunger, } \\
\text { Severe }\end{array}$ \\
\hline
\end{tabular}


Vita

\section{Me liss a We 6 ber}

270 McCullough Street Apt 2

Phone: (304) 322-0133

Morgantown, West Virginia 26505

melWV05@yahoo.com

Education: $\quad$ WEST VIRGINIA UNIVERSITY, Morgantown, West Virginia 26506. Pursuing a Masters of Science in Animal and Nutritional Sciences with a Major in Human Nutrition and Foods. Internship work specializing in: clinical and community dietetics and food service. Course work including biochemistry, physiology, maternal and child nutrition, and sports nutrition. To be graduated August 2007.

WEST VIRGINIA UNIVERSITY, Morgantown, West Virginia 26506. Obtained a Bachelor of Science in Family and Consumer Sciences with a major in Human Nutrition and Foods. Course work specializing in: nutrition, food science, and food service management, communications, and leadership. Graduated May 2003.

Professional Nutritionist, Monongalia County Health Department, Morgantown, West Experience: $\quad$ Virginia 26505.

Responsibilities included: Gather nutrition related information from parents/caregivers of low-income and provide relevant counseling; conduct nutrition education lessons in group and individual settings; evaluate group home menus and make recommendations for change.

Nutrition Graduate Assistant, Center For Excellence in Disabilities, West Virginia University, Morgantown, West Virginia 26506.

Responsibilities included: Assist in obtaining pre-clinic information, clinical assessments, and follow-up information of consumers participating in the Feeding and Swallowing Clinic.

Nutrition Services Volunteer, Mountainview Healthsouth Rehabilitation Hospital, Morgantown, West Virginia 26505.

Responsibilities included: Assist in gathering, reviewing, and correcting patients' menu choices; observe the dietitian during clinical rounds.

Work Customer Service Representative, TeleTech, Morgantown, West Virginia. Experience: $\quad$ Responsibilities included: Provide quality customer service in assisting customers nationwide with financial matters; routinely operate Microsoft Windows and DOS based programs. 
Child Care Provider, Pleasant Day Schools, Morgantown, West Virginia. Responsibilities included: Provide supervision of children during play and instructional activities; develop and implement daily lesson plans.

Attraction Operator and Receptionist, Valley World's of Fun, Fairmont, West Virginia.

Responsibilities included: Operate and maintain amusement attractions; assure customer safety; provide quality customer assistance.

Work

Experience (Cont.):

Office Assistant and Traffic Control, West Virginia Department of Highways, Ellenboro, West Virginia 26346.

Responsibilities included: Maintain employee, equipment and parts records; operate standard office equipment; assist with traffic control at work sites.

Cook, Roberto's, Pennsboro, West Virginia 26415.

Responsibilities included: Provide quality food in a timely manner; open and close restaurant; clean and sanitize.

Honors and West Virginia University, Morgantown, WV. Activities: Invited Honorary:

- Phi Upsilon Omicron

Organizations:

- American Dietetic Association

- Student Dietetic Association

- West Virginia University Marching Band

- Mountaineers For Christ student organization 